\title{
EXPLAINDIO UNTUK MENDESAIN ANIMASI PEMBELAJARAN INTERAKTIF
}

\author{
Rabiudin', Sitti Mulia ${ }^{2}$ \\ 1, Pendidikan Guru Madrasah Ibtidaiyah, Institut Agama Islam Negeri Sorong, Sorong, Indonesia \\ 2Pendidikan Biologi, Universitas Negeri Gorontalo, Gorontalo, Indonesia \\ rabiudin27@gmail.com
}

\begin{abstract}
Tujuan dari penelitian ini adalah untuk menghasilkan media animasi pembelajaran berbasis Explaindio pada materi struktur dan fungsi organ tubuh tumbuhan dengan tolak ukur layak digunakan dalam pembelajaran IPA di SMP atau MTS Kelas VIII. Metode yang digunakan dalam penelitian ini merujuk pada metode penelitian pengembangan model ADDIE dengan modifikasi ADDI. Tahapan penelitian ini mengikuti Tahapan Analysis, Design dan Develop, Peneliti tidak melanjutkan pada tahapan aveluate oleh karena waktu yang terbatas untuk melakukan penelitian ini serta cakupan penelitian yang terlalu luas. Peneliti menggunakan validator sebagai penilai media animasi yang peneliti kembangkan. Dalam melakukan penilaiannya validator memberikan saran saran sebagai perbaikan produk yang dikembangkan. Dari penilaian valitor ini peneliti mengolah datanya dan mendapatkan suatu kesimpulan bahwa media animasi berkaitan dengan materi struktur tubuh tumbuhan layak digunakan untuk dipakai di sekolah. Dengan kesimpulan penelitian bahwa hasil pengembangan animasi pembelajaran dengan Model ADDI pada materi struktur tubuh tumbuhan memenuhi syarat valid, reliable dan layak. Tahapan pengembangan media ajar ini melalui tahapan analysis kebutuhan siswa dan guru, desain animasi pembelajaran sesui dengan kebutuhan, pengembangan dari desain yang telah dilakukan dan implementasi atau menggunaan dari animasi yang dikembangkan. Proses pengembangannya menggunakan aplikasi Explaindio video creator dengan menggunakan tahapan sesuai kenerja aplikasi. Kesimpulan kelayakan ini diambil dari pembuktian hasil olah data penilaian tiga validator yang terdiri dari ahli media, ahli materi dan guru sekolah dengan skala reliabel mencapai 0,84 .
\end{abstract}

Key word: Animasi, Media, Pembelajaran

\section{Pendahuluan}

Secara umum, dalam proses pembelajaran ada beberapa aspek yang dianggap penting, beerupa keterampilan guru meengajar, fasilitas belajar, metode pembelajaran dan media pembelajaran. Saat guru berada dalam kelas maka aspek yang penting adalah pemilihan jenis metode dan keterampilan guru mengajar. Dua aspek ini mempengaruhi jenis media pembelajaran yang akan digunakan guru dalam mengajar. Dalam beberapa referensi dikatakan bahwa salah satu manfaat media pembelajaran ialah sebagai alat bantu mengajar yang ikut mempengaruhi keadaan, suasana, dan lingkungan belajar yang diatur dan direncanakan oleh guru (Arsyad, 2016: 84).

Kaitannya dengan media pembelajaran, maka kemajuan ilmu pengetahuan dan teknologi (IPTEK) dianggap memiliki pengaruh besar dalam dunia pendidikan. Pengaruh ini bisa ditinjau dari aspek penggunaan media dalam kegiatan mengajar guru yang sudah bervariasi. Kita mungkin pernah mendengar cerita orang-orang yang lahir di tahun 70-an, mereka belajar di sekolah hanya bermodalkan penjelasan langsung guru, tulisan di papan tulis, serta alat peraga manual yang sederhana. Dibandingkan dengan teknologi pembelajaran sekarang yang semakin maju, sehingga 
mendukung perbaikan kualitas pembelajaran. Pendidikan perlu memanfaatkan kemajuan ini agar mampu mencapai tujuannya secara efisien dan efektif. Guna meningkatkan efektivitas dan efisien pembelajaran, maka perlu dikembangkan berbagai pembelajaran kreatif dan inovasi. Hal ini perlu dilakukan agar kegiatan pembelajaran terkesan menarik serta tidak membosankan. Peran media berbasis IPTEK dalam proses pembelajaran memegang dalam proses pembelajaran (Arsyad, 2016: 19).

Dalam penggunaan media berbasis IPTEK dan digital, dibutuhkan keterampilan guru dalam penguasaan instrument media yang dimaksud. Misalnya, untuk dapat menyajikan presentasi yang baik, maka seorang guru butuh untuk belajar mendesain tampilan slide yang indah. Untuk dapat menggunakan media video atau animasi dalam pembelajaran, maka seorang guru harus menguasai teknik pembuatan video dan animasi yang dimaksud. Keterampilan guru dalam mendesain media ajar, menjadi kunci dalam suksesnya penggunaan media digital yang ada. Berkembanglah lirerasi digital dimana semua orang termaksud guru dan siswa untuk dapat mengoperasikan perangkat digital yang sedang berkembang. Dalam perkembangan inilah, menyebabkan media pembelajaran turut berkembang sesuai jenisnya, utamanya berkaitan dengan media ajar berbasis multimedia yang semakin berkembang, menyebabkan media pembelajaran semakin banyak bermunculan dan semakin mempermudah proses pembelajaran. Dengan menggunakan media ini, guru dapat menyampaikan materi dengan terstruktur serta bisa lebih jelas.

Mengenai efektifitas penggunaan media pembelajaran bahwa media pembelajaran sebagai salah satu faktor keberhasilan pembelajaran. Melalui penggunaan media belajar, peserta didik bisa termotivasi dan aktif untuk memaksimalkan semua indera peserta didik dalam kegiatan belajarnya dan menjadikan pembelajaran lebih bermakna. Ia juga mengatakan bahwa; "sebuah media merupakan sarana komunikasi dan sumber informasi yang akurat". Dimana media pembelajaran sebagai pembawa informasi dari sumber sebagai pemberi dan penerima dalam hal ini adalah siswa (Smaldino et.al, 2008: 45).

Dari beberapa referensi diatas, dikatakan bahwa media pembelajaran sering diartikan sebagi alat bantu atau instrumen yang dimanfaatkan dalam pembelajaran dengan maksud untuk menyampaikan pesan pembelajaran dari sumber informasi kepada penerima informasi. Media pembelajaran yang dapat digunakan untuk menunjang tugas guru dalam memotivasi dan meningkatkan pemahaman belajar siswa. Media pembelajaran dianggap sebagai hal yang urgen untuk syarat berlangsungnya proses pembelajaran di kelas dengan baik, yaitu pembelajaran yang kreatif, komunikatif dan inovatif guna mendukung dalam mengembangkan prestasi belajar peserta didik.

Berkaitan dengan perkembangan teknologi pembelajaran yang menjalar sampai pada penggunaan media digital dalam pembelajaran, maka ada dua media ajar yang sedang menjadi focus perhatian para guru dan pemerhati pendidikan. Penggunaan video pembelajaran dan animasi pembelajaran. Untuk penggunaan video pembelajaran telah banyak dilakukan oleh para guru, sebab dapat diamati langsung di channel youtube, dimana terkesan guru juga merangkap sebagai youtuber yang mengupload materi di internet. Yang jarang di explore oleh kebanyakan guru sebagai media pembelajaran adalah penggunaan animasi sebagai media pembelajaran utamanya dalam pembelajaran ilmu pengetahuan alam.

Dalam buku yang ditulis oleh Suyanto (2005: 20-21), Rosch dan McCornick mendefinisikan animasi sebagai percampuran antara program komputer dan video. Perpaduan ini dapat 
dipahami pada pemrograman computer dalam sebuah aplikasi yang mempu menghasilkan objek visual yang mampu bergerak sesuai arahan program dan tampilannya menyerupai video. Penekanan animasi sebagai media pembelajaran terdapat pada unsur visual dan audio yang dapat digunakan untuk meyampaikan isi materi ajar dari sumber belajar ke pembelajar yang dapat memacu dan merangsang pikiran, perhatian dan minat pembelajar serta dapat menyusun kembali informasi tersebut sehingga proses belajar menjadi lebih efektif. Sebagai pendukung penggunaan animasi sebagai media pembelajaran, dapat diamati bahwa saat ini animasi mengalami perkembangan jumlah pengguna beriringan dengan perkembangan teknologi yang turut meningkat. Untuk itu, animasi yang diterangkan dalam penelitian ini berupa gambar yang mengandung unsur tampilan visual dan audio. Sebagai program alat bantu sebagai animation maker, maka peneliti memilih explaindio video creator sebagai software dalam pembuatan animasi. Media belajar yang dibuat dengan Explaindio merupakan media yang mampu memberikan pengalaman yang dapat dilihat dengan mata sehingga dapat mengfokuskan perhatian dan memotivasi siswa dalam melaksanakan pembelajaran. Diharapkan dengan penggunaan animasi dalam pembelajaran maka dapat melibatkan unsur indera siswa untuk focus mengikuti kegiatan belajar (Smaldino et,al, 2008: 9).

Semakin banyaknya alat indera yang digunakan untuk menerima dan mengolah informasi, maka akan semakin besar pula kemungkinan informasi tersebut dipahami dalam ingatan. Hasil penelitiannya yang menyebutkan bahwa 90\% hasil belajar sesorang diperoleh melalui indera pandang dan hanya sekitar 5\% diperoleh melalui indera dengar, dan 5\% lagi melalui indera lain (Yulifar, 2017:2) Hasil penelitian perolehan hasil belajar melalui indera pandang berkisar 75\% dan melalui indera dengar 13\% serta melalui indera lainnya sekitar 12\% (Dale, 2011: 10).

Berkaitan dengan penggunaan media di sekolah, peneliti telah melakukan observasi di SMP N 3 Gorontalo pada pertengahan Oktober 2019, peneliti mengamati langsung dalam kelas dan berdiskusi langsung dengan guru di sekolah. Dari observasi ditemukan bahwa dalam perencanaan dan proses pembelajaran berjalan kurang baik, sebab kegiatan belajar didominasi oleh metode ceramah yang disertai dengan buku ajar dimana penampilan gambarnya kurang menarik. Dalam beberapa keadaan lain, ditemukan penggunaan media chart dan power point dari guru, namun desain medianya masih kaku seperti desain umumnya. Hal ini menyebabkan proses transfer materi ajar menjadi kurang bervariasi dan mengakibatkan banyaknya kendala dalam tercapainya tujuan pembelajaran seperti yang ditargetkan. Olehnya pengembangan atau pembaharuan media perlu dilakukan inovasi dan variasi guna menyajikan pembelajaran yang lebih terukur, variatif dan efektif sehingga tujuan pembelajaran dapat tercapai.

Penelitian ini menempatkan animasi pembelajaran berbasis Explaindio sebagai opsi dalam menunjang kegiatan pembelajaran di kelas. Animasi pembelajaran berbasis Explaindio dilihat sebagai medium yang memperantarai individu memahami materi ajar dengan baik sebab dapat membangkitkan motivasi belajar siswa.

\section{Metode Penelitian}

Penelitian ini termasuk dalam jenis penelitian pengembangan (research and development). Tempat penelitian ini dilaksanakan di SMP N 3 Kota Gorontalo, Kelurahan Liluwo, Kecamatan Kota Tengah, Kota Gorontalo, Provinsi Gorontalo. Alasan memilih sekolah ini karena siswa kelas VIII di sekolah ini banyak yang memiliki hasil belajar yang rendah, sebab kebanyakan bermain game 
yang berbasis animasi. Sehingga peneliti tertarik untuk menunjukan sisi lain pemanfaatan animasi yang bisa digunakan dalam belajar.

Prosedur penelitian ini mengikuti model pengembangan ADDI. Alasan menggunakan model ini karena model pengembangan ADDI sederhana namun penerapanya sistematis sehingga membuat peneliti lebih mudah dalam menghasilkan suatu produk. Dalam hal ini model ADDIE dimodifikasi menjadi ADDI, terdiri dari tiga tahapan pengembangan yaitu Analysis (analisis), Design (desain), dan Development (pengembangan) (Wilkinson, 1994: 34). Dalam penelitian ini, tahap Implementasi ditiadakan karena tahap implementasi menguji coba produk dalam skala luas, sedangkan tahap evalusi ditiadakan karena pada tahap evalusi mengukur capain hasil pembelajaran terkait dengan pengembangan media yang akan dihasilkan. Teknik pengumpulan data yang digunakan dalam penelitian ini menggungakan angket atau Kuesioner. Angket digunakan untuk mengetahui tanggapan ahli (validator) mengenai pengembangan media pembelajaran menggunakan aplikasi Explaindio, serta untuk mengetahui kelayakan produk sebagai dasar untuk merevisi produk agar produk lebih baik lagi. Instrumen penilain menggunakan skala Likert, yaitu 4=sangat baik, 3=baik, 2=kurang, dan 1=sangat kurang. Penelitian pengembangan media pembelajaran dengan media Explaindio ini menggunakan analisis data deskriptif kualitatif pada bagian proses pengembangan untuk mengetahui penilaian dan pendapat dari produk yang dihasilkan

\section{Hasil dan Pembahasan}

Beberapa tahapan dalam penelitian mengikuti tahapan penelitian pengembangan model ADDI yang meliputi Analisis masalah dan kebutuhan, Pendefinisian indicator dalam proses pengembangan, serta Pengembangan dan penilaian produk animasi pembelajaran biologi. Secara terperinci penggunaan model ADDI dalam penilitian ini diuraikan berikut ini:

Tahap Analisis; tahapan ini dilakukan untuk menganalisis syarat-syarat pengembangan melalui studi pendahuluan dan kajian literatur. Adapun studi pendahuluan yang dilakukan antara lain: berdiskusi dengan guru mata pelajaran IPA yang ada di SMPN 3 Negeri Kota Gorontalo, serta menganalisis masalah mendasar yang dihadapi dalam mengajar mulai dari perencanaan, pelaksanaan proses pembelajaran hingga hasil belajar siswa. Kajian literatur berupa dokumen hasil supervisi KBM, dan dokumen kurikulum dan dokumen hasil penilaian guru dan sekolah terhadap hasil belajar siswa. Tahap analisis ini terdiri atas:

Analisis Kebutuhan Dalam Pembelajaran; dilakukan dalam penelitian ini meliputi faktor-faktor pendukung dan penghambat proses pembelajaran yang dimiliki setiap siswa, dari temuan yang didapatkan di lapangan siswa menginginkan media pembelajaran yang berbeda dengan sajian dalam buku ajar dengan metode penyampaian yang sesuai dengan pengetahuan mereka. Siswa juga menginginkan media belajar yang dapat membangkitkan semangat belajar dan memotivasi mereka untuk bertahan belajar lebih lama. Dari penelitian dalam kelas ini didapatkan topik materi pelajaran yang benar-benar dibutuhkan siswa, format materi pelajaran yang tepat untuk disajikan, penjabaran materi yang mudah dipahami oleh siswa, serta pemilihan topik materi yang dapat meningkatkan minat belajar siswa. Analisis kebutuhan ini diawali dari kegiatan mengumpulkan informasi dan berakhir pada perumusan masalah. Dalam tahap pengumpulan informasi, peneliti telah melakukan pengamatan pada objek penelitian ini sehingga didapatkan informasi mengenai kendala yang dialami oleh guru dan siswa selama proses pembelajaran berlangsung, Cara guru memanfaatkan sumber belajar yang sudah ada, kualitas keterampilan guru selama memberikan materi pelajaran, serta kemampuan guru dalam mengevaluasi hasil belajar siswa. 
Dari tahapan diatas disimpulkan bahwa guru dan siswa di SMP Negeri 3 Kota Gorontalo membutuhkan media pembelajaran yang sesuai dengan kemampuan belajar siswa dan kompetensi dasar yang dapat diajarkan dengan mudah oleh guru.

a. Analisis terhadap masalah yang dihadapi; Sesuai dengan hasil diskusi dengan guru matapelajaran dan pengamatan dalam kelas, pada tahap ini peneliti menemukan berbagai masalah dalam pembelajaran IPA di sekolah, diataranya: kurangnya pengetahuan dan keterampilan guru dalam memanfaatkan animasi pembelajaran yang baik, rendahnya motivasi belajar siswa, adanya kejenuhan siswa dalam belajar sehingga menyebabkan rendahnya hasil belajar siswa. Temuan ini dijadikan dasar dalam pengembangan animasi pembelajaran dengan menggunakan Model ADDI.

b. Analisis kompetensi; Pada tahap ini ditelusuri kompetensi yang dimiliki siswa yang menjadi sasaran penggunaan animasi pembelajaran. Hal ini melingkupi semua proses pembelajaran disesuaikan dengan kompetensi yang dimiliki siswa antara lain: kemampuan akademik yang sesuai dengan standar KKM bidang studi masih agak rendah, kemampuan kerja kelompok yang masih kurang bersinergi, kemampuan menganalisis dan memecahkan masalah yang masih lemah. Melalui Hasil study dokumen penilaian siswa menggambarkan bahwa data nilai raport semester ganjil pada kelas VIII yang berjumlah 27 orang menunjukkan kemampuan siswa pada mata pelajaran IPA sebagian besar berada di bawah kriteria ketuntasan minimum (KKM) dengan standar 75.

c. Hasil yang dicapai; Dalam tahap ini peneliti melakukan pengamatan langsung melalui dokumen kurikulum tentang hasil capaian siswa selama satu semester sebelumnya. Dalam dokumen penilaian hasil belajar terdiri atas ranah kognitif yang meliputi pengetahuan yang dimiliki siswa, afektif yang terdiri dari kepribadian dan sikap siswa selama proses pembelajaran berlangsung serta psikomotor yang meliputi keterampilan yang dimiliki siswa.

Hasil diskusi dengan guru matapelajaran didapatkan bahwa kemampuan kognitif siswa masih rendah sebab terdapat sekitar $45 \%$ siswa yang memiliki nilai dibawah KKM, nilai afektif pun demikian, minat belajar siswa dalam kelas masih menjadi keluhan mendasar guru. Kemampuan psikomotorik juga masih dibawah standar sebab format LKS yang digunakan masih belum mampu menggali kemampuan keterampilan siswa secara menyeluruh, sebab hanya berdasar penugasan berbasis bahan bacaan dalam buku ajar, bukan pada pengamatan melalui media atau pengamatan langsung.

Tahap Desain Media Animasi Pembelajaran; Tahap desain pembelajaran bertujuan untuk merancang media animasi pembelajaran. Kegiatan yang dilakukan pada tahap ini adalah perencanaan alat bahan yang dibutuhkan dalam desain media animasi pembelajaran, proses pembuatan animasi hingga proses konversi menjadi video animasi dalam bentuk MP4. Berikut beberapa tahapan tersebut.

a. Persiapan Aplikasi Explaindio; Untuk mendapatkan aplikasi explaindio maka peneliti melakukan pencarian di Google dan menemukan aplikasi ini dengan versi terbaru, kemudian peneliti mempelajari proses penggunaan aplikasi ini dalam pembuatan animasi. Setelah itu Peneliti menginstal explaindio, namun karena aplikasi ini berbayar, Maka saya menggunakan sistem crack supaya bisa digunakan dalam waktu yang lama tanpa ada ada Watermark dari produk sistem aplikasi. Setelah itu dilakukan pemasangan (Instal) aplikasi ini di dalam laptop yang memiliki spesifikasi memori RAM 4 Giga dan memori eksternal 1 Tera dan Core i3. Setelah itu peneliti mulai menggunakan aplikasi ini dalam mendesain animasi pembelajaran. 
Singkatnya dari tampilan di layar laptop terlihat bahwa Aplikasi ini sangat sederhana sebab memiliki menu yang sedikit. Sebenarnya dalam software yang diperjualbelikan hanya terdapat satu CD yang memuat software aplikasi ini yang berlisensi, dimana setelah diinstal, maka diminta untuk memasukkan serial number. Ketika serial number nya benar maka aplikasi ini langsung berfungsi dengan baik. Sebenarnya jika kita menggunakan sistem cracknya maka ini melanggar hak cipta aplikasi akan tetapi karena peneliti tidak memiliki akses untuk membeli aplikasi ini juga tidak memiliki materi yang cukup, maka peneliti menggunakan sistem crack untuk mendapatkan aplikasi ini.

b. Pesiapan Gambar dan Materi Struktur tubu tumbhan; Aplikasi explaindio sejauh ini hanya mengolah animasi Dua dimensi. Oleh karena keterbatasan ini, maka peneliti juga menggunakan gambar-gambar Dua dimensi. Dalam aplikasi explaindio tidak tersedia menu untuk menggambar atau mengsketsa gambar sendiri dalam aplikasi. Namun kita diperbolehkan untuk mengimpor gambar dari luar dalam bentuk JP, PNG, video serta animasi yang lainnya. Karena kekurangan sistem untuk menggambar dalam aplikasi ini, maka peneliti menggunakan gambar-gambar di luar aplikasi yang berkaitan dengan materi struktur tubuh tumbuhan. Peneliti mengambil gambar-gambar tersebut dari pencarian Google kemudian disimpan di folder dalam laptop lalu diimpor kembali dalam frame aplikasi, selanjutnya bisa digunakan dalam slide dan diatur sesuai tata letak masing-masing. Sebelum proses pengambilan gambar, maka peneliti terlebih dahulu membaca materi ajar kemudian memetakan gambar apa saja yang dibutuhkan dalam materi agar penjelasan dalam animasi sesuai dengan gambar yang diinput.

c. Input data gambar dan materi dalam aplikasi; Dalam proses editing, gambar-gambar yang dimasukkan dalam slide aplikasi disertai dengan keterangan dan penjelasan yang disesuaikan dengan materi ajar yang menjadi fokus penelitian yaitu struktur tubuh tumbuhan. Serangkaian materi slide yang ditampilkan bersamaan dengan gambar dimaksudkan untuk mempermudah proses pengenalan materi dimana siswa bisa melihat secara langsung apa yang sedang dipelajari tanpa harus menghayal lebih jauh terkait dengan materi ajar.

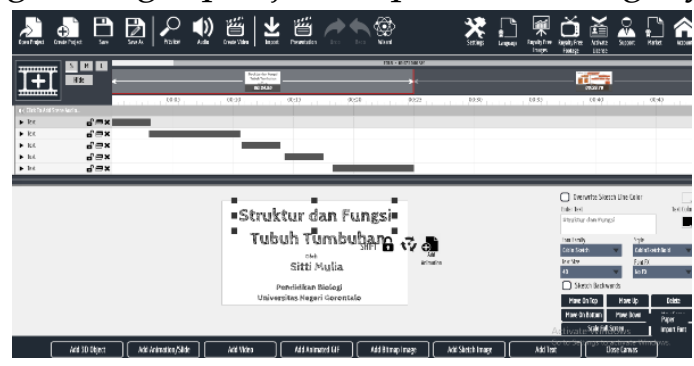

Gambar Proses pengimputan Materi

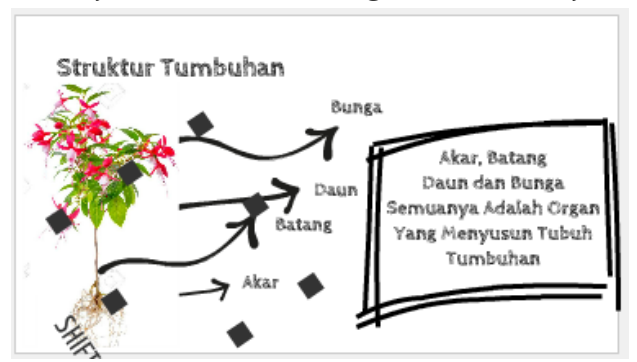

Gambar Proses pengimputan Gambar

Pada tahapan ini pula maka peneliti mengatur letak gambar menggunakan ikon-ikon dalam aplikasi untuk di hubungkan dengan materi ajar serta mengatur bentuk huruf serta warna huruf yang diinginkan agar tampilan animasi dapat menarik minat belajar siswa

d. Penyesuaian desain frame dan pengaturan waktu penampilan; Setelah semua gambar dan materi terinput dalam sistem aplikasi, kemudian peneliti mengatur durasi waktu masingmasing gambar serta waktu tampilan masing-masing slide. Tahapan ini merupakan tahapan yang agak rumit sebab peneliti harus menyesuaikan durasi tampilan gambar berdasarkan tingkat pemahaman atau kecepatan membaca para peserta didik karena jika slide terlalu cepat maka dikhawatirkan tidak akan terbaca penjelasan materi ajar dan jika terlalu lambat maka 
akan membosankan siswa dalam mengikuti proses belajar. Olehnya pada tahap ini peneliti fokus dalam mengatur durasi waktu masing-masing slide agar bisa berjalan sesuai dengan apa yang diinginkan oleh peserta didik. Berikut tampilan media dalam pengaturan durasi waktu animasi.

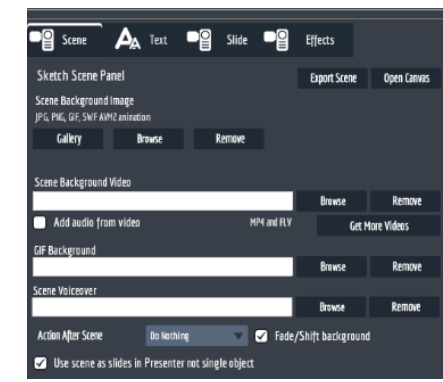

Gambar Proses Pengaturan Teks dan

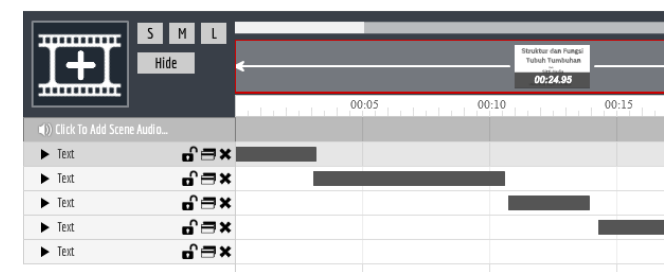

Gambar Proses pengaturan waktu dalam

Pada tahapan ini pula dilakukan pengaturan warna latar animasi menyesuaikan dengan sinkronisasi warna antara beberapa warna yang diinginkan oleh eh peneliti. Meskipun demikian peneliti juga tetap memperhatikan aspek keterbacaan gambar dan materi serta kehalusan warna agar tidak terkesan mencolok. Setelah itu Peneliti menambahkan beberapa gambar bergerak seperti sketsa tangan atau Sketsa spidol yang menjelaskan dan bergerak di depan slide. Selain itu dilakukan juga pembenahan warna pada huruf yang digunakan dalam penjelasan materi serta icon-icon lain yang ditampilkan dalam slide animasi hingga akhirnya animasi siap untuk diproduksi.

e. Rendering animasi; Tahapan ini ini dilakukan setelah semua item dalam animasi sudah selesai baik meliputi pengaturan tampilan, pengaturan waktu, maupun pengaturan materi sehingga dapat dikatakan bahwa tahapan ini adalah proses pengalihan dari bahan mentah animasi menjadi bahan jadi animasi yang siap dikonversi menjadi video MP4 yang layak ditonton oleh peserta didik. Berikut cara rendering dalam proses konversi menjadi video MP4

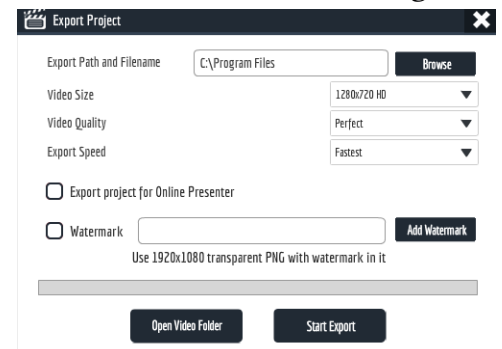

Gambar Cara mengekspor File ke Vido

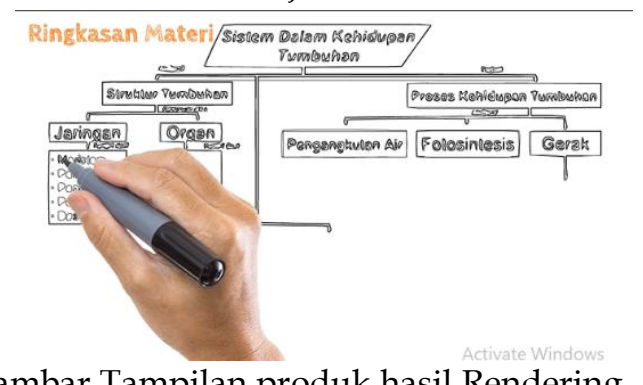

Gambar Tampilan produk hasil Rendering

Sebelum proses render berlangsung, ketika peneliti meng-klik export video maka akan muncul kotak dialog yang menanyakan dimanakah file animasi ini akan disimpan. Olehnya peneliti memilih folder yang memiliki kapasitas besar untuk penyimpanan video produk animasi yang dibuat. Kemudian menunggu hingga beberapa menit sampai proses render selesai. Semakin banyak slide atau frame yang dibuat dalam aplikasi explaindio maka semakin lama waktu render selesai. Selanjutnya aplikasi siap untuk diajukan kepada validator untuk dinilai.

Tahap Development; Sesuai dengan tahapan yang digunankan oleh Thiagarajan maka kegiatan ini dibagi menjadi expert appraisal dan developmental testing. Expert appraisal merupakan teknik untuk menilai kelayakan rancangan produk dengan validasi oleh ahli dalam bidangnya. Sementara itu saran-saran yang diberikan ahli digunakan untuk memperbaiki animasi pembelajaran yang disusun. Developmental testing merupakan kegiatan uji coba rancangan animasi 
pembelajaran ini pada sasaran objek yang sesungguhnya dalam hal ini siswa dan diamati oleh pengamat guru bidang studi. Pada saat uji coba ini dicari data respon, reaksi atau komentar dari sasaran objek (siswa dan pengamat). Hal ini mendukung data pengamatan observer. Hasil uji coba digunakan memperbaiki animasi. Setelah diperbaiki kemudian diuji kembali sampai memperoleh hasil yang efektif. Dalam konteks pengembangan animasi pembelajaran, kegiatan pengembangan dilakukan dengan langkah-langkah sebagai berikut:

a) validasi materi pembelajaran; hal-hal yang divalidasi meliputi: 2 aspek yaitu: 1) aspek pembelajaran yang terdiri dari kesesuaian materi dengan kompetensi inti (KI), kompetensi dasar (KD), indikator pencapaian kompetensi, kejelasan indikator keberhasilan, ketepatan materi, kejelasan contoh yang diberikan, pemberian latihan, urutan penyajian materi, manfaat gambar, animasi untuk penjelasan materi. Selanjutnya aspek ke 2 yaitu aspek kebahasaan yang terdiri dari: kesesuaian bahasa dengan tingkat berpikir siswa, kemudahan materi, ketepatan tata bahasa dan ejaan, serta kelugasan bahasa. Tim ahli yang dilibatkan dalam proses validasi terdiri dari para pakar bidang studi pada mata pelajaran IPA.

b) validasi video pembelajaran; hal-hal yang divalidasi meliputi 3 aspek yaitu aspek tampilan, aspek pemrograman, serta aspek kelengkapan media. Aspek tampilan terdiri dari ketepatan memilih background, keserasian warna, kejelasan gambar, ketepatan ukuran gambar, ketepatan jenis, variasi dan huruf, komposisi tampilan layout dan ketertarikan pada animasi. Sedangkan aspek pemrograman terdiri dari kemudahan berinteraksi, ketertarikan menu, efisiensi tulisan, kemudahan mencari materi. Selanjutnya aspek kelengkapan animasi yang terdiri dari kelengkapan daftar materi, kelengkapan judul dan keterangan judul, serta kelengkapan gambar.

Adapun hasil validasi animasi pembelajaran dalam penelitian pengembangan ini berupa saran atau masukan untuk revisi animasi dan juga skor penilaian dari para ahli sebagai berikut; Media Pembelajaran yang divalidasi oleh para ahli dikembangkan berdasarkan 8 komponen atau indikator, yakni ; (1) Media Pembelajaran sesuai dengan Materi (2), Media Sesuai dengan Tujuan Pembelajaran (3) Mendukung Isi Bahan Pembelajaran, (4) Menarik Perhatian Siswa (5) Bermakna, (6) Mudah dipahami siswa, (7) Sesuai dengan taraf berpikir siswa, (8) menimbulkan gairah belajar. Revisi media pembelajaran berdasarkan masukan para ahli dapat dilihat pada tabel berikut:

Tabel 1: Revisi Media Pembelajaran Berdasarkan Masukan Para Ahli

\begin{tabular}{|c|c|c|}
\hline Bagian direvisi & Sebelum direvisi & Sesudah direvisi \\
\hline Lembaran frame & $\begin{array}{l}\text { Lembaran slide perlu } \\
\text { dipisahkan per pertemuan }\end{array}$ & Sudah dipisahkan sesui RPP. \\
\hline Tampilan gambar & $\begin{array}{l}\text { Tulisan pada gambar dibuat } \\
\text { lebih besar }\end{array}$ & $\begin{array}{l}\text { Sudah diperbaiki, sehingga } \\
\text { tulisan dapat dibaca }\end{array}$ \\
\hline
\end{tabular}

Sumber: Analisis Data Peneliti

Sementara itu, hasil penilaian dari 3 validator terhadap Media Pembelajaran sebagai berikut:

Tabel 2. Penilaian validator terhadap Media Pembelajaran

\begin{tabular}{|c|c|c|c|c|c|c|c|c|c|}
\hline \multirow{2}{*}{ Item } & \multicolumn{3}{|c|}{ Validator } & \multicolumn{3}{|c|}{ Selisi } & \multirow{2}{*}{ Jml-k } & \multirow{2}{*}{ Validity } & \multirow{2}{*}{ Ket } \\
\hline & 1 & 2 & 3 & 1 & 2 & 3 & & & \\
\hline \multicolumn{10}{|l|}{ Validasi Materi } \\
\hline Kesesuaian Materi dengan SK \& KD & 4 & 4 & 4 & 3 & 3 & 3 & 9 & 1 & Valid \\
\hline Keakutaran Materi & 3 & 3 & 4 & 2 & 2 & 3 & 7 & 0,7778 & Valid \\
\hline Pendukung materi Pembelajaran & 4 & 3 & 3 & 3 & 2 & 2 & 7 & 0,7778 & Valid \\
\hline Kemutakhiran Data dan Materi & 3 & 4 & 3 & 2 & 3 & 2 & 7 & 0,7778 & Valid \\
\hline
\end{tabular}




\begin{tabular}{lllllllllll}
\hline & \multirow{2}{*}{ Item } & \multicolumn{1}{c}{ Validator } & \multicolumn{3}{c}{ Selisi } & \multirow{2}{*}{ Jml-k } & \multirow{2}{*}{ Validity } & \multirow{2}{*}{ Ket } \\
\cline { 2 - 5 } & 1 & 2 & 3 & 1 & 2 & 3 & & & \\
\hline Validasi Media & 4 & 3 & 4 & 3 & 2 & 3 & 8 & 0,8889 & Valid \\
Efek Suara & 4 & 3 & 4 & 3 & 2 & 3 & 8 & 0,8889 & Valid \\
Kemudahan Pengoperasian & 3 & 3 & 3 & 2 & 2 & 2 & 6 & 0,6667 & Valid \\
Konsistensi & 3 & 4 & 4 & 2 & 3 & 3 & 8 & 0,8889 & Valid \\
Format & 2 & 4 & 4 & 1 & 3 & 3 & 7 & 0,7778 & Valid \\
Organisasi & 3 & 3 & 4 & 2 & 2 & 3 & 7 & 0,7778 & Valid \\
Kefektifan & 4 & 4 & 4 & 3 & 3 & 3 & 9 & & 1 & Valid \\
Kemanfaatan & & & & & & & 0,8384 & \\
\hline \multicolumn{1}{c}{ Rata-rata } & & & & & & & & \\
\hline
\end{tabular}

Sumber: Analisis Data Peneliti

Hasil perhitungan penilaian validator terhadap butir/komponen Media Pembelajaran, menunjukkan bahwa dari 3 orang validator memberikan penilaian terhadap Media Pembelajaran diperoleh butir 1,5,6,8 diiinterpretasikan "sangat sesuai" dengan rentang nilai 3,6-4.0. Kemudian butir 2, 3, 4, 7, 9 dan 10 diinterpretasikan " sesuai " dengan rerata nilai 3.0-3,3. Hasil analisis validitas isi setiap butir yang dihitung dengan menggunakan rumus Aiken (Aiken, L. R. 1985), diperoleh bahwa indeks validasi semua butir antara 0,6667 - 0,889 dengan kesimpulan "Valid". Hasil analisis ini kemudian diperkuat dengan hasil perhitungan kekonsistenan penilaian validator yang diperoleh dari koefisien reabilitas yaitu sebesar 0,84, perhitungan lebih jelas terdapat pada lampiran.

Tahap Implementation (Implementasi); Pada tahapan ini peneliti menggunakan media animasi yang telah dikembangakan untuk digunakan dalam kegiatan pembelajaran IPA, Peneliti telah memilih siswa kelas VIII SMP Negeri 3 Kota Gorontalo sebagai sasaran dari tahapan impelentasi ini. diawali dengan diskusi singkat dengan guru mata pelajaran IPA sebelum tahapan pengembangan hingga koordinasi untuk tahapan implementasi produk pengemangan di sekolah yang sama. Jumlah siswa di sekelas VIII adalah 26 anak yang terdiri dari 11 laki laki dan 15 perempuan dengan kecenderungan tingkat kecerdasan siswa tersebar secara merata. Peneliti melakukan uji coba pada jam pelajaran ke dua yang berkisar pada pukul 08.50-10.30 WIT. Sebagai indicator keberhasilah pada tahapan ini, maka peneliti menggunakan dua indicator penilaian yaitu observasi aktifitas belajar siswa dan tanggapan Siswa terhadap media.

Tabel Observasi aktifitas belajar siswa

\begin{tabular}{|c|c|c|c|c|}
\hline \multirow{2}{*}{$\begin{array}{l}\text { Proses } \\
\text { Belajar }\end{array}$} & \multirow{2}{*}{ Aktifitas Siswa } & \multicolumn{3}{|c|}{ Penialanan } \\
\hline & & 5 & $\begin{array}{llll}4 & 3 & 2 & 1\end{array}$ & 1 \\
\hline & Siswa telah siap mengikuti pelajaran & $\sqrt{ }$ & & \\
\hline Pendahuluan & Siswa mendengarkan Arahan Guru & & $\sqrt{ }$ & \\
\hline & Siswa Memperhatikan Tampilan video & $\sqrt{ }$ & & \\
\hline & Siswa mengikuti arahan guru terhadap video & & $\sqrt{ }$ & \\
\hline Proses & Siswa aktif mengerjakan Lembar Kerja & & $\sqrt{ }$ & \\
\hline Pembelajaran & Siswa bersemangat mengikuti pelajaran & $\sqrt{ }$ & & \\
\hline & Siswa aktif menyelesaikan tugas pembelajaran & $\sqrt{ }$ & & \\
\hline & Siswa mampu membuat kesimpulan & & $\sqrt{ }$ & \\
\hline Penutup & $\begin{array}{l}\text { Siswa menunjukan rasa penasaran dengan media } \\
\text { animasi }\end{array}$ & $\sqrt{ }$ & & \\
\hline
\end{tabular}


Dari data hasil observasi aktivitas belajar siswa dengan menggunakan media animasi dalam pembelajaran dapat dilihat bahwa dari semua indikatot pengamatan, berada pada angka 5 dan 4 yang itu memiliki interpretasi baik dan sangat baik. Adapun indicator pengamatan yang mendapatkan nilai sangat baik adalah Siswa telah siap mengikuti pelajaran, siswa memperhatikan tampilan video, siswa bersemangat mengikuti pelajaran, siswa aktif menyelesaikan tugas pembelajaran dan siswa menunjukan rasa penasaran dengan media animasi. Sementara itu yang berada pada kategori baik adalah siswa mendengarkan arahan Guru, Siswa mengikuti arahan guru terhadap video, Siswa aktif mengerjakan lembar kerja dan siswa mampu membuat kesimpulan. Dari beberapa item pengamatan tersebut tidak ada yang memiliki nilai 3, 2 dan 1, yang berarti bahwa tidak ada indicator pengamatan dengan katergori buruk atau tidak baik. Olehnya itu penggunaan media animasi ini dapat diterimah dan digunakan di sekolah Penelitian ini bertujuan untuk menghasilkan animasi pembelajaran IPA Terpadu yang layak dan efektif digunakan dalam pembelajaran. Penelitian pengembangan animasi pembelajaran ini dilakukan melalui beberapa tahapan kegiatan berdasarkan model pengembangan ADDI. Hasil penelitian menunjukkan bahwa, animasi pembelajaran yang telah dirancang peneliti dan divalidasi oleh para ahli diperoleh hasilnya berupa animasi pembelajaran yang valid dan reliabel dengan kesimpulan sangat layak digunakan. Hasil validasi yang telah dilakukan oleh para ahli ini berupa saran atau masukan yang disertai penilaian terhadap masing-masing animasi. Saran atau masukan para ahli atau validator diolah secara statistik untuk dijadikan dasar pengambilan keputusan apakah animasi tersebut valid dan reliabel.

Media Pembelajaran yang divalidasi oleh para ahli dikembangkan berdasarkan 8 komponen atau indikator, yakni ; (1) Media Pembelajaran sesuai dengan Materi (2), Media Sesuai dengan Tujuan Pembelajaran (3) Mendukung Isi Bahan Pembelajaran, (4) Menarik Perhatian Siswa (5) Bermakna , (6) Mudah dipahami siswa, (7) Sesuai dengan taraf berpikir siswa, (8) Menimbulkan Gairah Belajar.

Hasil perhitungan penilaian validator terhadap butir/komponen Media Pembelajaran, menunjukkan bahwa dari 3 orang validator memberikan penilaian terhadap Media Pembelajaran diperoleh butir 1,5,6,8 diiinterpretasikan "sangat sesuai" dengan rentang nilai 3,6 - 4.0. Kemudian butir 2, 3, 4, 7, 9 dan 10 diinterpretasikan " sesuai " dengan rerata nilai 3.0-3,3. Hasil analisis validitas isi setiap butir yang dihitung dengan menggunakan rumus Aiken, diperoleh bahwa indeks validasi semua butir antara 0,6667 - 0,8889 dengan kesimpulan "Valid". Hasil analisis ini kemudian diperkuat dengan hasil perhitungan kekonsistenan penilaian panelis yang diperoleh dari koefisien reabilitas yaitu sebesar 0,84 .

Selain itu pada proses implementasi, ditemukan hasil observasi aktifitas belajar siswa menunjukan dukungan terhadap penerapan produk animasi pembelajaran untuk dipakai dalam kegiatan belajar IPA di kelas. Dengan adanya beberapa pembuktian ketuntasan dalam pengunaan animasi ini, maka model pengembagan ADDI dianggap bisa menjadi alternative dalam pengembangan animasi pembelajaran. Hal ini disebabkan oleh langkah-langkah pengembangan animasi penelitian yang terurut meski peneliti dalam penelitian ini tidak sampai pada tahapan implementasi dan evaluasi. Selain itu, dalam proses pengembangannya, maka aplikasi explaindio bisa menjadi alternatif untuk digunakan dalam mengunjang produk animasi pembelajaran yang memiliki kualitas bagus serta proses pembuatan yang lebih muda dari pada aplikasi lainnya. 


\section{Kesimpulan}

Berdasarkan hasil penelitian, maka dapat diambil kesimpulan bahwa hasil pengembangan animasi pembelajaran materi struktur tubuh tumbuhan dengan Model ADDI pada materi struktur tubuh tumbuhan memenuhi syarat valid, reliable dan efektif. Tahapan pengembangan media ajar ini melalui tahapan analysis kebutuhan siswa dan guru, desaign animasi pembelajaran sesuai dengan kebutuhan, pengembangan dari desain yang telah dilakukan dan implementasi atau menggunaan dari animasi yang dikembangkan. Proses pengembangannya menggunakan aplikasi Explaindio animasi creator dengan menggunakan tahapan sesuai kenerja aplikasi. Kesimpulan ini diambil dari pembuktian hasil olah data penilaian tiga validator yang terdiri dari ahli media, ahli materi dan guru sekolah dengan skala reliabel mencapai 0,84 yang menunjukan bahwa media animasi pembelajaran dapat digunakan dalam pembelajaran IPA di SMP atau MTs.

\section{Referensi}

Ayuningrum. 2012. Pengembangan Media Video Pembelajaran untuk Siswa Kelas X pada Kompetensi Mengolah Soup Kontinental di SMK N 2 Godean. Skripsi tidak diterbitkan, Yogyakarta: FT Universitas Negeri Yogyakarta.

Andrees Darius. 2018. Membuat Video Professional yang Menarik Perhatian Hanya Dalam Beberapa Menit. Seri Academic Press di bidang komunikasi, jaringan dan multimedia.

Davis, A.L, 2013. Menggunakan prinsip desain instruksional untuk mengembangkan informasi media yang efektif: Model ADDIE. Berita Perpustakaan Perguruan Tinggi \& Riset, 74(4), 205-207.

Aiken, L. R. (1985). Tiga Koefisien untuk Menganalisis Reliabilitas dan Validitas Peringkat. $\begin{array}{llll}\text { Pengukuran Pendidikan dan } & \text { 131-142. }\end{array}$ https://doi.org/10.1177/00131644854 51012

Arsyad, Azhar. 2016. Media Pembelajaran. Jakarta: Rajawali Pers.

Smaldino, dkk. 2008. Teknologi instruksional dan Media Pembelajaran.

Suyanto. 2005. Analisis \& desain aplikasi multimedia untuk pemasaran. Penerbit Andi Publisher

Yulifar, M. 2017. Penerapan Media Pembelajaran Livewire Simulations Pada Rangkaian

Listrik Arus Searah Di Sma Muhammadiyah 2 Pontianak. Pendidikan Fisika FKIP Untan Pontianak 